\title{
Diet Impact on Obesity beyond Calories and Trefoil Factor Family 2 (TFF2) as an Illustration: Metabolic Implications and Potential Applications
}

\author{
Abdelaziz Ghanemi ${ }^{1,2}\left(\mathbb{D}\right.$, Mayumi Yoshioka ${ }^{1,2}$ (D) and Jonny St-Amand ${ }^{1,2, *(D)}$ \\ 1 Functional Genomics Laboratory, Endocrinology and Nephrology Axis, CHU de Québec-Université Laval \\ Research Center, Québec, QC G1V 4G2, Canada; abdelaziz.ghanemi@crchudequebec.ulaval.ca (A.G.); \\ mayumi.yoshioka@crchudequebec.ulaval.ca (M.Y.) \\ 2 Department of Molecular Medicine, Faculty of Medicine, Laval University, Québec, QC G1V 4G2, Canada \\ * Correspondence: jonny.st-amand@crchudequebec.ulaval.ca; Tel.: +1-(418)-654-2296
}

\section{check for} updates

Citation: Ghanemi, A.; Yoshioka, M.; St-Amand, J. Diet Impact on Obesity beyond Calories and Trefoil Factor Family 2 (TFF2) as an Illustration: Metabolic Implications and Potential Applications. Biomolecules 2021, 11, 1830. https://doi.org/10.3390/ biom 11121830

Academic Editors: Maria

Vittoria Micioni Di Bonaventura and Mariangela Pucci

Received: 28 October 2021

Accepted: 3 December 2021

Published: 4 December 2021

Publisher's Note: MDPI stays neutral with regard to jurisdictional claims in published maps and institutional affiliations.

Copyright: (c) 2021 by the authors. Licensee MDPI, Basel, Switzerland. This article is an open access article distributed under the terms and conditions of the Creative Commons Attribution (CC BY) license (https:/ / creativecommons.org/licenses/by/ $4.0 /)$.

\begin{abstract}
Obesity is a health problem with increasing impacts on public health, economy and even social life. In order to reestablish the energy balance, obesity management focuses mainly on two pillars; exercise and diet. Beyond the contribution to the caloric intake, the diet nutrients and composition govern a variety of properties. This includes the energy balance-independent properties and the indirect metabolic effects. Whereas the energy balance-independent properties are close to "pharmacological" effects and include effects such as antioxidant and anti-inflammatory, the indirect metabolic effects represent the contribution a diet can have on energy metabolism beyond the caloric contribution itself, which include the food intake control and metabolic changes. As an illustration, we also described the metabolic implication and hypothetical pathways of the high-fat diet-induced gene Trefoil Factor Family 2. The properties the diet has can have a variety of applications mainly in pharmacology and nutrition and further explore the "pharmacologically" active food towards potential therapeutic applications.
\end{abstract}

Keywords: obesity; diet; calories; energy metabolism; trefoil factor family member 2; high-fat diet

\section{Obesity and the Ongoing Coronavirus Disease 2019 Crisis}

Obesity, as an epidemic health problem [1], represents a topic of a continuously increasing number of studies surrounding different fields, ranging from obesity development and pathogenesis to the related diseases and health problems, at different life stages and physiological or pathological statuses. The basic definition of obesity is a lost balance between energy intake and energy expenditure that leads to an accumulation of excessive calories, mainly as lipid storage within the adipocytes in a distribution pattern that depends on genetic and environmental factors [2,3]. Such energy imbalance results from the superiority of the energy intake represented by the food intake compared to the energy expenditure represented mainly by the basal metabolic rate [4], physical activity/exercise [5,6] and thermogenesis [7-9]. Obesity can also develop as results of gene disruption or deficiency, such as the Brd2 gene $[10,11]$ and the leptin gene $[12,13]$, both leading to metabolic pathways towards an obesity-related phenotype. In addition, obesity has also epigenetics factors [14-17]. The related adiposity distribution depends on many factors and also impacts the pathological outcomes of obesity [18]. The pathogenesis of obesity has been discussed from a variety of perspectives, including broken energy homeostasis [18], microbiota contribution [19], neuroendocrine reprogramming [20] and even toward considering obesity as a disease [2,21]. The complexity of the molecular and cellular mechanisms governing obesity establishment, development and pathogenesis are poorly understood, which limits its research advances and therefore the development of efficient molecular therapies. The danger of obesity and increased adiposity results 
from their various impacts on health in terms of diseases risks and disturbed biological functions [22]. That includes metabolic disorders [23], cardiovascular diseases [24,25], dyslipidemia [26], impaired regeneration [27], inflammation [28], kidney disease [29], cancer [30], diabetes [24], impacts on immunity and antibodies [31-34], age-related cognitive decline [35], respiratory complications [36,37] and infertility [38,39].

It is worth noting that the ongoing coronavirus disease 2019 (COVID-19) crisis has increased the importance of obesity research because of both the impact of the COVID-19 pandemic (and the related measures [40,41]) on obesity development [42] as well as the obesity-induced increased vulnerability to COVID-19 [43-45]. The measures imposed by the governments and health authorities, including confinement and its consequences (sedentary lifestyle, reduced physical activity, increased food intake, disturbed sleeping, etc. $[41,42,46])$ are towards worsening obesity rates worldwide. This includes the greater stress that was related to a higher body mass index, an increased working time, a higher anxiety level and less time to spend on weight management efforts [47] during this COVID-19 crisis. On the other hand, obesity consequences on the prognosis of patients with COVID-19 include increased hospitalization, intensive care unit admission and mortality [48]. The mechanisms beyond such increased vulnerability are diverse and include the chronic inflammatory character of obesity [49], immune dysregulation [50], excessive oxidative stress [51] and probably metabolic dysfunction and endothelium imbalance as well [52]. Furthermore, in addition to the direct impact of obesity on COVID-19 severity, obesity would also have indirect impacts on COVID-19. Obesity-related diseases and health conditions represent risk factors toward increasing the vulnerability to COVID-19. Diabetes, one of the most known diseases associated with obesity [53,54], represents a risk factor for severe COVID-19 [55-57]. Cardiovascular diseases, which have their risks increased in obese patients [25,58,59], also represent risk factors for COVID-19 [60]. Other obesity-related health problems, such as hypertension and kidney and liver diseases [57], do represent risk factor for the severe forms of COVID-19. In addition, studies have also explored the fact that COVID-19 could also worsen or lead to other health problems, including diabetes [56,61], and possibly lead to a post-COVID-19 multi-level health crisis [62]. That would lead to a vicious cycle involving obesity, diabetes and COVID-19, among other pathologies that also increase COVID-19 severity. Moreover, the impacts of obesity on immunity [31-34] threaten to reduce the efficacy of anti-COVID-19 vaccines [63] that represent the best hope for humans to see an end of this pandemic.

The heavy consequences of obesity on health as well as on economy [64] and society $[65,66]$ have led to the development of various pharmacotherapies [67] for obesity and the necessity to have other medications in development [68]. However, the main approaches to manage obesity remain exercise $[69,70]$ and diet [71]. Along with the energy expenditure (exercise [6], thermogenesis [72], etc.), the diet represents the energy intake part of the caloric balance. Therefore, it is important to describe the nutritional aspects of the diet. Thus, the main focus of the nutritional research in obesity emphasizes the caloric density and the need to limit the caloric intake [73] to create a caloric deficiency leading to adiposity reduction and weight loss. Within this context, high-fat diet (HFD) and high-sugar diet have a high importance. HFD diet is characterized by both its high caloric density and a limited satiety. In addition, sugar consumption has even been described in the context of addiction [74] that contributes to obesity development [75]. Furthermore, the combined effect of high fat and high sugar has the most deleterious effects, as suggested by the work of Ghosh et.al. [76]. This gives both HFD and high-sugar diet a special status within nutrition research in the context of obesity and weight management.

\section{Diet and Calories-Independent Patterns}

The important diet caloric contribution to obesity is well documented, and various diets have been studied and compared in the context of prevention and treatment of obesity [77-83]. The research "obesity-diet" mainly focuses on controlling/limiting the caloric intake to manage obesity or reduce the adiposity. We describe fat and sugar diets 
as key contributors to the caloric intake. However, sugar and lipids cannot be seen only as caloric resources or "fuel"; they also play important biological roles within the cellular and subcellular structures, biochemical pathways, heat insulation, etc. Similarly, and in addition to the important direct impacts diet has on obesity, the in vivo diet consequences include two main patterns, energy balance-independent and those indirectly impacting the energy metabolism. In these two, the diet not only directly impacts the energy balance by increasing the caloric intake. The energy balance-independent diet benefits are close to "pharmacological" effects in which the diet elements can be described as functional foods or nutraceuticals [84-89]. Indeed, diet contents have been reported with a variety of properties that can be pharmacologically explored, including antioxidant pattern [90,91], anti-inflammatory [92,93], anti-microbial, anti-fungal, anti-diabetic and anti-atherosclerotic activity [94], anticancer properties [95,96], antiviral effects [97], body weight lowering fibers [98], protection against endogenous exposure to persistent organic pollutants [99] and gut microbiota changes [99]. In addition, consumption of elements, such as calcium (calories-free), has also been shown to impact obesity development [100,101]. Furthermore, some compounds from vegetables and fruits can be converted to hormone-like active substances with biological actions [102]. All these elements illustrate how the diet impacts on obesity go beyond the caloric density (quantity) but also include the diet composition (quality) as exemplified in Figure 1. Thus, a balanced diet within an anti-obesity approach should not be limited to a caloric intake control but needs also to make use of such "pharmacological" properties to both optimize the anti-obesity effects and also obtain effects such as anti-inflammation that will counteract outcomes seen during obesity (inflammation, increased risk cancer, etc.). Within this context, some concepts reported in the literature, such as "eat to treat" [103] would find there explanatory mechanisms and underlying pathways in those calorie-independent impacts of diet. Some of these properties (potential antimicrobial, antioxidant and anti-inflammatory) have also led researchers to suggest the Mediterranean diet as a nutritional approach for COVID-19 [104].

On the other hand, the second perspective is that dietary elements can indirectly impact the energy metabolism. Among the good examples are: (i) the red pepper decreases appetite [105], reduces fat intake [106] and increases satiety [107], (ii) oligofructose reduces hunger [108], (iii) dietary fiber potentiates weight regulation [109] and (iv) fenugreek fiber reduces energy intake and increases satiety [110]. In addition, the increased insulin resistance following the ingestion of a protein source mirroring western diet (compared to provision of casein) [111], prevention of obesity-related glucose intolerance by the salmon peptide fraction [112], the benefits of fish oil on diet-induced insulin resistance [113], the fish oil diet induced both reduction in body weight gain in ob/ob mice [114] and improvement of glucose intolerance in HFD-fed mice [115], the role of n-3 polyunsaturated fatty acid in insulin resistance prevention [116] that involve controlling adipose tissue inflammation in its mechanism [117], HFD effects on gut hormones production [118], the HFD-induced reduction of the sensitivity to satiety signals [119], blood lipid profile and body fat distribution improvement with fish oil [120], and appetite control [121] and food intake modification [122] of coffee/caffeine are also important illustrative properties mediated by diet and represent an indirect energy balance management. All these paths represent illustrations of how selecting diet can impact the energy balance and the metabolism beyond the simple caloric intake related to the diet (Figure 2). These properties can be explored to optimize nutritional approaches and therapeutic development. This field is well supported by functional genomics studies exploring the transcriptomic changes depending on the diet [123] which highlight the links between the regulated genes and the related underlying metabolic pathways. 


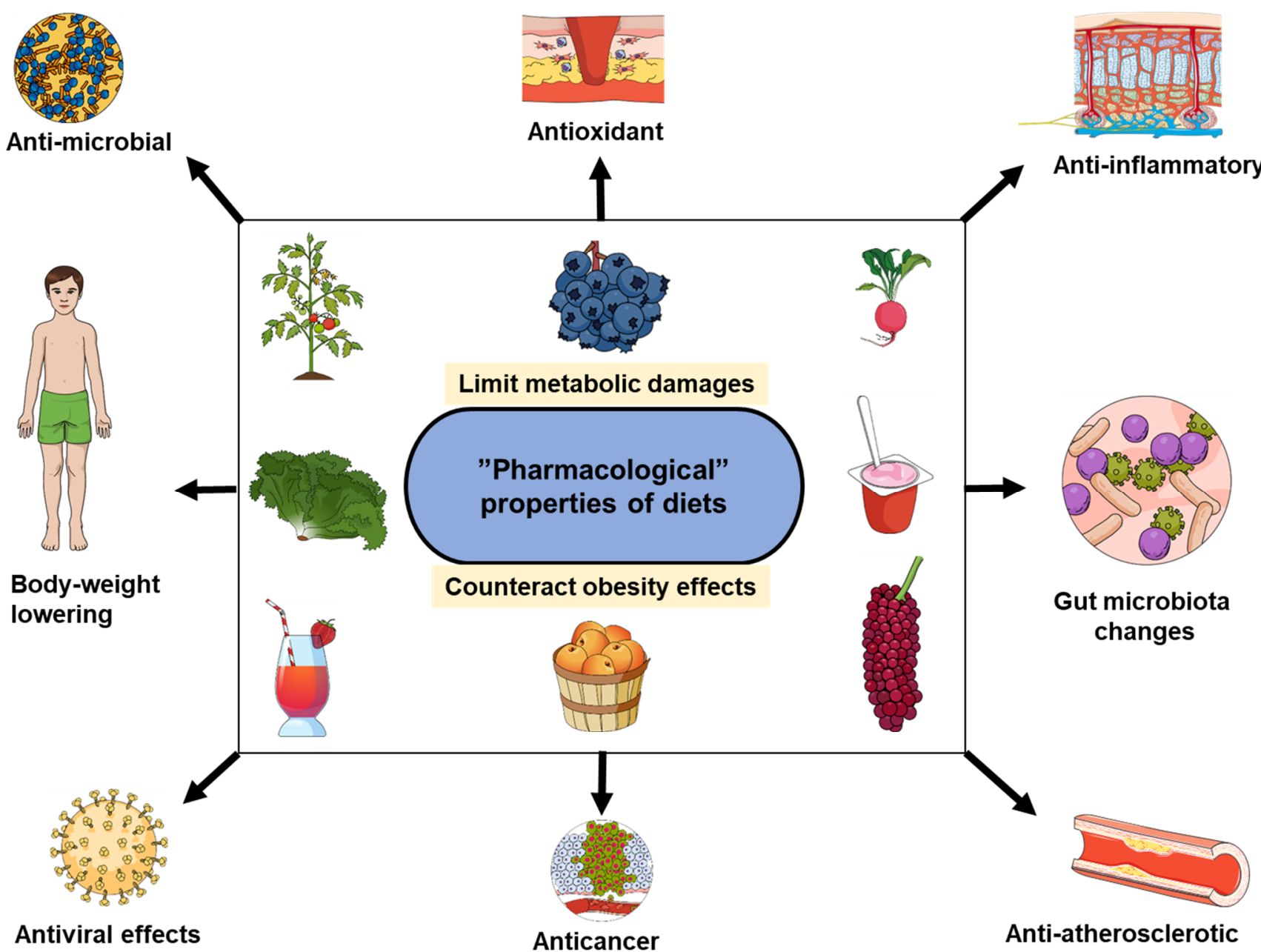

Figure 1. The energy balance-independent diet benefits are close to pharmacological effects. The diverse benefits related to food include properties that counteract consequences of obesity, such as inflammation, cancer risk and metabolic damages.

Moreover, the key consequences of the diet on microbiota composition, which has a significant metabolic importance, reflects another indirect impact diet has on energy balance. Indeed, some diets rich in or with a supplementation of probiotics, prebiotics or synbiotics can modulate the microbiota [124]. For instance, a pro-inflammatory gut microbiota development is promoted by HFD [125], and no microbiota composition pattern was associated with vegan or vegetarian diets [126] which reflects some microbiota effects. The microbiota changes result in adaptations, including metabolic improvement $[127,128]$ and even improving/treating obesity [19,124,129]. Importantly, the fact that different diets lead to different changes in gut microbiota composition [130] and that different diets also lead to different transcriptome expression [123] both suggest a diet-specific metabolic phenotype. Beyond the aspects of potential therapeutic effect and the impacts a diet has on biological processes, including genes and metabolic pathways represents a growing area that could lead to therapeutic applications.

In addition to obesity, ageing also represents an important risk factor for a variety of diseases and health problems including cardiovascular disease [131], loss of neuroplasticity [132], cerebral ischemia [133], osteoporosis [134], pulmonary disease, cancer [135] and neurodegenerative disease [136]. Therefore, healthy ageing will contribute to reducing the risk and the severity of various diseases. For that, a healthy lifestyle that includes, in addition to exercise [137-139], sleep quality [140] and metal health [141], optimized diets choice is a key to achieve healthy ageing. Within this context, and based on the ageingrelated pathways, mainly the oxidative stress [142] and redox regulation [143] involving reactive oxygen and nitrogen species [135] and free radicals [144,145], a diet of selected 
properties would contribute to healthy ageing. Indeed, food and beverages with properties ranging from antioxidant [146] and anti-inflammatory to anticancer and metabolic benefits will reduce the risks associated with ageing. For instance, diet choice toward white meat and fish can reduce the risk of age-related cognitive decline [147], and dietary antioxidants contribute to healthy ageing [148]. Such impacts of diet management in ageing [146] will lead to further development of geriatrics and elderly care beyond pharmacology.
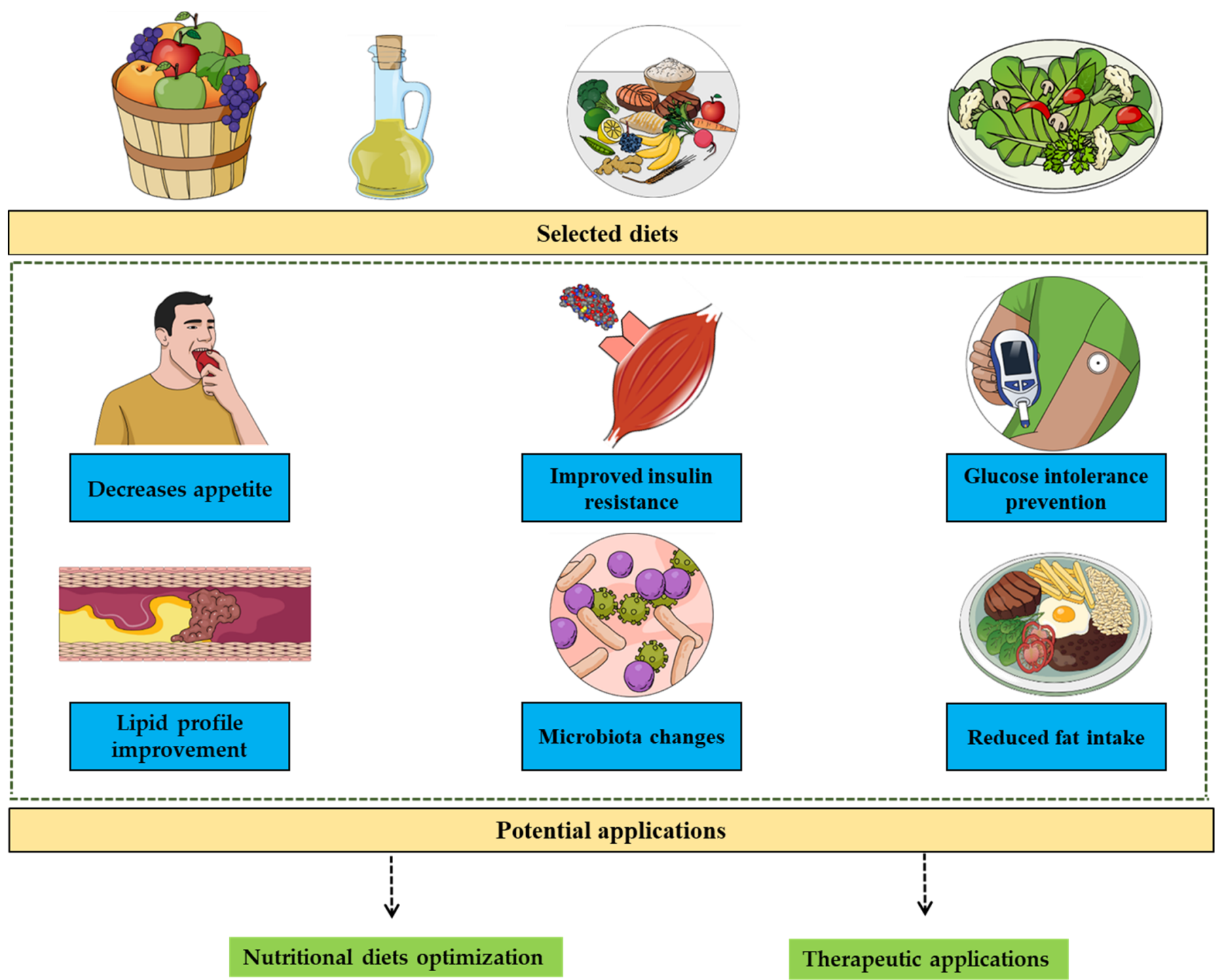

Figure 2. Indirect impacts diet has on energy metabolism. Some diets have the ability to impact the energy metabolism through insulin sensitivity improvement, appetite control, microbiota changes-related metabolic changes and improving the lipids profile. These properties are independent from the caloric intake that comes with such diets due to caloric independent-patterns.

\section{Diet and Trefoil Factor Family: From Gastrointestinal Protection to Metabolic Implications}

Following the same line of thought highlighting the indirect impacts of the diet, we provide an illustrative example of the indirect impacts of diet on energy balance mediated by trefoil factor family (TFF). Indeed, the indirect effect on metabolism can also be illustrated by the diet consequences on selected metabolic patterns related to the energy balance through the TFF. The TFF is a family of secreted protease-resistant peptides [149] with intramolecular disulfide bonds [150], trefoil domain(s) [151] and Cterminal dimerization domain, and which have important roles in mucosal protection 
and post-injury mucosal repair [152], epithelial migration promotion [153] and mucosal healing [154]. Whereas Tff1, Tff2 or Tff3 knock-out (KO) in mice led to gastrointestinal impairment [155], TFF have a therapeutic potential to treat gastrointestinal disorders [156]. While TFF1, or pS2, is expressed mainly in the stomach [152] without a known receptor (although a basolateral binding site in the gastrointestinal epithelial was suggested for the three TFFs [150]) or detailed metabolic implications, TFF3, or ITF, expressed in both the small (duodenum, jejunum and ileum) and large intestine [152] and in other tissues, such as the liver [157] and the nervous system [158], is still without a validated receptor [159,160], but its expression is regulated by food intake [161]. The metabolic implications of TFF3, although not well known, are also worth exploring as it has been shown to regulate the glucose metabolism in the liver [157], and its deficiency leads to an affected hepatic lipid metabolism but with an improved glucose utilization [162]. On the other hand, TFF3 improves HFD-induced hepatic steatosis [163] and, in a diet-induced obesity mouse model, TFF3 improved glucose tolerance [161].

On the other hand, TFF2, known as spasmolytic peptide (SP), is a very stable small protein [164] expressed in the duodenum [152], the stomach, the colon, immune organs, leucocytes [164], macrophages, spleen cells [165], lymphocytes [165] hypothalamus [166] and the kidneys [167]. Unlike TFF1 and TFF3, it has been further studied in diverse context, including the energy metabolism. Indeed, TFF2 has been shown/suggested to play roles in anti-inflammatory pathways $[165,168]$, counteracting the immune-mediated damage resulting from the HFD [169] and immune response [165,170]. Among the TFFs, TFF2 has been shown to play a role in obesity and metabolic disorders, mainly after its characterization as an HFD-induced gene and the work that explored its metabolic implications. Briefly, functional genomics studies characterized Tff2 as an HFD-induced gene [171,172]. Thus, TFF2/Tff2 expression has been suggested as an indicator of the severity of the HFD-induced obesity with a variety of potential applications [173]. Importantly, Tff2 KO protected the mice from the HFD-induced obesity [166], which was explained by a metabolic phenotype toward an increased energy expenditure [174]. As an attempt to explain all these findings, we have hypothesized that the HFD-induced overexpression of TFF2 would represent a mechanism of adaptation to the HFD ingestion leading to an increased lipid absorption and storage via TFF2-stimulated receptors, as we previously reviewed [175]. This correlates with the exacerbated weight loss resulting from TFF2 deficiency [164].

Regarding the molecular and cellular pathways beyond such TFF2 metabolic roles, we highlight the receptor chemokine (C-X-C motif) receptor 4 (CXCR4), that belongs to the important family of $G$ protein-coupled receptor [176,177], which is a known TFF2 receptor, including in cancer cell lines [178]. For instance, during development, the embryonic insulin-producing cells are maintained by the TFF2/CXCR4 axis [179]. This could indicate an insulin-mediated metabolic implication of TFF2, especially that cell proliferation in pancreatic $\beta$-cells is promoted by TFF2 through CXCR-4-mediated phosphorylation [180], and the Tff2 $\mathrm{KO}$ reduced insulin serum levels in mice [166]. Furthermore, the expression of CXCR4 in key metabolic tissues, such as the liver [181], adipose tissue [182] and muscles [183] as well as the central nervous system [184] and the digestive tract [185], correlates with the metabolic changes observed in Tff2 $\mathrm{KO}$ mice. Moreover, the increased expression of CXCR4 in situations in which TFF2 is also overexpressed, such as cancer [181,186], further supports such molecular links. Importantly, the CXCR4-defeciency in adipocytes leads to exacerbated obesity and impairs the brown adipose tissue thermoregulatory process [182]. This correlated with our previous hypothesis in which TFF2 would be a signal aiming to limit the food intake and obesity development since CXCR4 deficiency would prevent TFF2 from playing the related metabolic roles in limiting obesity and thus, explains the exacerbated obesity.

In addition, the fact that Tff2 $\mathrm{KO}$ mice have an increased expression of agouti-related protein (AgRP) in the arcuate nucleus of the hypothalamus [166] may suggest that the HFD-induction of Tff2 [171,172] could limit the expression (or at least prevent the increased expression seen in Tff2 KO mice) of AgRP and thus limit its orexigenic and energy ex- 
penditure reduction effects [187], thus supporting the hypothesis that TFF2 could be a lipid-induced signal aiming to shift the energy balance towards counteracting the HFDrelated excessive caloric intake. On the other hand, the melanocortin system, involved in the control of energy balance [188-190], receptors have AgRP as their antagonists [191]. Thus, suggesting a possible molecular link between TFF2 and the melanocortin system via the AgRP. The underlying molecular pathways are yet to be elucidated, and other works pointed out the need to clarify the roles of miRNAs in the TFF2-related processes $[149,155]$.

The interesting part of TFF is that they are mainly expressed in the gastrointestinal system [152,192-194] which is the location in which the nutrients are fully digested into their basic forms to be absorbed $[195,196]$. Thus, there would be potential pathways according to which there is a detection of those nutrients [197] in the gastrointestinal system resulting in regulatory signals sent to the energy metabolism tissues (both regulatory as well as the key metabolic tissues) to trigger biological processes toward a metabolic adaptation [198] to such energy intake depending on the detected nutrients. This explains that stomach and intestine represents the starting point of energy balance regulatory signals as candidates for pharmacological targeting of TFF. Regarding TFF2 perspectives, the ultimate goal would be to identify a targetable lipid-specific signaling pathway(s) in order to control the food intake as well as other metabolic patterns. Unlike glucoses, for which we have the insulin as an induced acute regulatory metabolic signal, we are yet to identify a lipid-specifically induced acute signals equivalent to insulin. Identifying such signal(s) would allow researchers to target the food intake and control the appetite. The rationale beyond the potential targeting of TFF2 is that Tff2 expression is induced by HFD within $30 \mathrm{~min}$ from the meal intake, a perfect therapeutic timing. Although we have the leptin concertation that changes with adiposity/obesity development [199-201] as well as fasting and re-feeding [202-204], identifying acute appetite/metabolic signals specific for lipids would still represent a key breakthrough with various therapeutic and mechanistic potential applications and implications.

\section{Perspectives}

The traditional approach of measuring the impact of diet on energy metabolism and obesity was limited to the mathematical evaluation of the caloric intake as compared to the energy expenditure. Now, the new advances on food chemistry and the related biological impacts allow researchers to expand the approach of diet impacts on obesity development beyond the direct caloric input. The diet can directly influence the energy balance toward certain metabolic phenotypes or can induce signals, such as TFF2, that would modify metabolic pathways (indirect impact of the diet). These concepts related to the non-caloric patterns of the diet would allow a deeper exploration of how diet choices affect the energy balance. Therefore, allowing an optimization of the diet in order to target specific pathways depending on the metabolic needs. Within this context, we can think about a dietary "metabolic enhancer" as a potential approach within an anti-obesity therapy.

There is also a need to consider the potential pharmacotherapies that might be prescribed at the same time with a specific diet. For instance, a specific diet could activate a pathway or a biochemical reaction that deactivates a pharmacological agent and thus results in therapeutic inefficacy. Therefore, related pharmacovigilance [205] to map the line between the pharmacology and the toxicology [206,207] both in vivo and in vitro [208] remains required. However, the interaction between diet and pharmacology could be positive as shown by the omega- 3 polyunsaturated fatty acid that improve the responsiveness to ursodeoxycholic acid during autoimmune liver diseases and cholestatic [209]. Thus, a specific diet choice could turn into a therapeutic adjuvant.

The education and the culture of the lifestyle habits related to diet should not be limited to the caloric balance and nutritional needs, such as vitamins and minerals, but should go beyond that toward the concept of "nutraceutical" $[87,210]$ as a pharmacologically active food with potential therapeutic applications. Such approaches will provide additional tools 
to manage diseases, such as obesity, ageing and metabolic disorders and thus, optimize medical care.

Author Contributions: A.G. designed the manuscript structure and wrote it. A.G., M.Y. and J.S.-A. discussed the content and exchanged ideas and suggestions (concepts to add, the figures, references selection, etc.) throughout the writing process, edited and critically revised the paper. J.S.-A. gave the final approval for the version to be published. All authors have read and agreed to the published version of the manuscript.

Funding: This work received no external funding.

Institutional Review Board Statement: Not applicable.

Informed Consent Statement: Not applicable.

Data Availability Statement: Not applicable.

Acknowledgments: Abdelaziz Ghanemi received a scholarship under the Merit Scholarship Program for foreign students from the Ministry of Education and Higher Education of Quebec, Canada. The Fonds de recherche du Québec-Nature et technologies (FRQNT) is responsible for managing the program (Bourses d'excellence pour étudiants étrangers du Ministère de l'Éducation et de l'Enseignement supérieur du Québec, Le Fonds de recherche du Québec-Nature et technologies (FRQNT) est responsable de la gestion du programme). Abdelaziz Ghanemi received the scholarship «Bourse Tremplin -Stage en milieu de pratique» (Internship scholarship) from the Fonds de recherche du Québec-Sante (FRQS), Quebec, QC, Canada. Figures were created using images from https: // mindthegraph.com/ and http://smart.servier.com. Servier Medical Art by Servier is licensed under a Creative Commons Attribution 3.0 Unported License (accessed on 18 October 2021).

Conflicts of Interest: The authors declare no conflict of interest.

\section{References}

1. Caballero, B. Humans against Obesity: Who Will Win? Adv. Nutr. 2019, 10, S4-S9. [CrossRef]

2. Ghanemi, A.; St-Amand, J. Redefining obesity toward classifying as a disease. Eur. J. Intern. Med. 2018, 55, 20-22. [CrossRef] [PubMed]

3. Apovian, C.M. Obesity: Definition, comorbidities, causes, and burden. Am. J. Manag. Care 2016, 22, s176-s185.

4. Hulbert, A.J.; Else, P.L. Basal metabolic rate: History, composition, regulation, and usefulness. Physiol. Biochem. Zool. 2004, 77, 869-876. [CrossRef]

5. van Baak, M.A. Physical activity and energy balance. Public Health Nutr. 1999, 2, 335-339. [CrossRef]

6. Westerterp, K.R. Exercise, energy balance and body composition. Eur. J. Clin. Nutr. 2018, 72, 1246-1250. [CrossRef]

7. Saito, M.; Matsushita, M.; Yoneshiro, T.; Okamatsu-Ogura, Y. Brown Adipose Tissue, Diet-Induced Thermogenesis, and Thermogenic Food Ingredients: From Mice to Men. Front. Endocrinol. 2020, 11, 222. [CrossRef]

8. Roesler, A.; Kazak, L. UCP1-independent thermogenesis. Biochem. J. 2020, 477, 709-725. [CrossRef] [PubMed]

9. Fenzl, A.; Kiefer, F.W. Brown adipose tissue and thermogenesis. Horm. Mol. Biol. Clin. Investig. 2014, 19, 25-37. [CrossRef]

10. Wang, F.; Deeney, J.T.; Denis, G.V. Brd2 gene disruption causes "metabolically healthy" obesity: Epigenetic and chromatin-based mechanisms that uncouple obesity from type 2 diabetes. Vitam. Horm. 2013, 91, 49-75. [CrossRef] [PubMed]

11. Wang, F.; Liu, H.; Blanton, W.P.; Belkina, A.; Lebrasseur, N.K.; Denis, G.V. Brd2 disruption in mice causes severe obesity without Type 2 diabetes. Biochem. J. 2009, 425, 71-83. [CrossRef] [PubMed]

12. Rossi, H.L.; Raj, N.R.; Marquez de Prado, B.; Kuburas, A.; Luu, A.K.S.; Barr, G.A.; Recober, A. Trigeminal Pain Responses in Obese ob/ob Mice Are Modality-Specific. Neuroscience 2019, 415, 121-134. [CrossRef]

13. Lindström, P. beta-cell function in obese-hyperglycemic mice [ob/ob Mice]. Adv. Exp. Med. Biol. 2010, 654, 463-477. [CrossRef]

14. Lopomo, A.; Burgio, E.; Migliore, L. Epigenetics of Obesity. Prog. Mol. Biol. Transl. Sci. 2016, 140, 151-184. [CrossRef]

15. Ling, C.; Rönn, T. Epigenetics in Human Obesity and Type 2 Diabetes. Cell Metab. 2019, 29, 1028-1044. [CrossRef] [PubMed]

16. Rohde, K.; Keller, M.; la Cour Poulsen, L.; Blüher, M.; Kovacs, P.; Böttcher, Y. Genetics and epigenetics in obesity. Metab. Clin. Exp. 2019, 92, 37-50. [CrossRef] [PubMed]

17. Ghanemi, A.; Yoshioka, M.; St-Amand, J. Ageing and Obesity Shared Patterns: From Molecular Pathogenesis to Epigenetics. Diseases 2021, 9, 87. [CrossRef]

18. Ghanemi, A.; Yoshioka, M.; St-Amand, J. Broken Energy Homeostasis and Obesity Pathogenesis: The Surrounding Concepts. J. Clin. Med. 2018, 7, 453. [CrossRef] [PubMed]

19. Lim, Y.Y.; Lee, Y.S.; Ooi, D.S.Q. Engineering the Gut Microbiome for Treatment of Obesity: A Review of Current Understanding and Progress. Biotechnol. J. 2020, 15, e2000013. [CrossRef]

20. Ghanemi, A.; Yoshioka, M.; St-Amand, J. Obesity as a Neuroendocrine Reprogramming. Medicina 2021, 57, 66. [CrossRef]

21. Conway, B.; Rene, A. Obesity as a disease: No lightweight matter. Obes. Rev. 2004, 5, 145-151. [CrossRef] [PubMed] 
22. Ghanemi, A.; Yoshioka, M.; St-Amand, J. Obese Animals as Models for Numerous Diseases: Advantages and Applications. Medicina 2021, 57, 399. [CrossRef]

23. Després, J.P.; Lemieux, I. Abdominal obesity and metabolic syndrome. Nature 2006, 444, 881-887. [CrossRef]

24. Piché, M.E.; Tchernof, A.; Després, J.P. Obesity Phenotypes, Diabetes, and Cardiovascular Diseases. Circ. Res. 2020, 126, 1477-1500. [CrossRef]

25. Piché, M.E.; Poirier, P.; Lemieux, I.; Després, J.P. Overview of Epidemiology and Contribution of Obesity and Body Fat Distribution to Cardiovascular Disease: An Update. Prog. Cardiovasc. Dis. 2018, 61, 103-113. [CrossRef] [PubMed]

26. Vekic, J.; Zeljkovic, A.; Stefanovic, A.; Jelic-Ivanovic, Z.; Spasojevic-Kalimanovska, V. Obesity and dyslipidemia. Metabolism 2019, 92, 71-81. [CrossRef] [PubMed]

27. Ghanemi, A.; Yoshioka, M.; St-Amand, J. Regeneration during Obesity: An Impaired Homeostasis. Animals 2020, 10, 2344. [CrossRef]

28. Stolarczyk, E. Adipose tissue inflammation in obesity: A metabolic or immune response? Curr. Opin. Pharm. 2017, 37, 35-40. [CrossRef]

29. Silva Junior, G.B.; Bentes, A.C.; Daher, E.F.; Matos, S.M. Obesity and kidney disease. J. Bras. Nephrol. 2017, 39, 65-69. [CrossRef]

30. Kolb, R.; Sutterwala, F.S.; Zhang, W. Obesity and cancer: Inflammation bridges the two. Curr. Opin. Pharm. 2016, 29, 77-89. [CrossRef]

31. Fang, X.; Henao-Mejia, J.; Henrickson, S.E. Obesity and immune status in children. Curr. Opin. Pediatr. 2020, 32, 805-815. [CrossRef]

32. Ghanemi, A.; Yoshioka, M.; St-Amand, J. Impact of Adiposity and Fat Distribution, Rather Than Obesity, on Antibodies as an Illustration of Weight-Loss-Independent Exercise Benefits. Medicines 2021, 8, 57. [CrossRef] [PubMed]

33. Andersen, C.J.; Murphy, K.E.; Fernandez, M.L. Impact of Obesity and Metabolic Syndrome on Immunity. Adv. Nutr. 2016, 7, 66-75. [CrossRef]

34. Rojas-Osornio, S.A.; Cruz-Hernández, T.R.; Drago-Serrano, M.E.; Campos-Rodríguez, R. Immunity to influenza: Impact of obesity. Obes. Res. Clin. Pract. 2019, 13, 419-429. [CrossRef]

35. Bischof, G.N.; Park, D.C. Obesity and Aging: Consequences for Cognition, Brain Structure, and Brain Function. Psychosom. Med. 2015, 77, 697-709. [CrossRef]

36. Xanthopoulos, M.; Tapia, I.E. Obesity and common respiratory diseases in children. Paediatr. Respir. Rev. 2017, $23,68-71$. [CrossRef] [PubMed]

37. Jubber, A.S. Respiratory complications of obesity. Int. J. Clin. Pract. 2004, 58, 573-580. [CrossRef] [PubMed]

38. Best, D.; Bhattacharya, S. Obesity and fertility. Horm. Mol. Biol. Clin. Investig. 2015, 24, 5-10. [CrossRef] [PubMed]

39. Silvestris, E.; de Pergola, G.; Rosania, R.; Loverro, G. Obesity as disruptor of the female fertility. Reprod. Biol. Endocrinol. 2018, 16, 22. [CrossRef]

40. Ghanemi, A.; Yoshioka, M.; St-Amand, J. Coronavirus Disease 2019 (COVID-19) Crisis Measures: Health Protective Properties? Medicines 2021, 8, 49. [CrossRef]

41. Ammar, A.; Brach, M.; Trabelsi, K.; Chtourou, H.; Boukhris, O.; Masmoudi, L.; Bouaziz, B.; Bentlage, E.; How, D.; Ahmed, M.; et al. Effects of COVID-19 Home Confinement on Eating Behaviour and Physical Activity: Results of the ECLB-COVID19 International Online Survey. Nutrients 2020, 12, 1583. [CrossRef]

42. Ghanemi, A.; Yoshioka, M.; St-Amand, J. Will an obesity pandemic replace the coronavirus disease-2019 (COVID-19) pandemic? Med. Hypotheses 2020, 144, 110042. [CrossRef]

43. Kwok, S.; Adam, S.; Ho, J.H.; Iqbal, Z.; Turkington, P.; Razvi, S.; Le Roux, C.W.; Soran, H.; Syed, A.A. Obesity: A critical risk factor in the COVID-19 pandemic. Clin. Obes. 2020, 10, e12403. [CrossRef]

44. Ghanemi, A.; Yoshioka, M.; St-Amand, J. Coronavirus Disease 2019 (COVID-19) Crisis: Losing Our Immunity When We Need It the Most. Biology 2021, 10, 545. [CrossRef] [PubMed]

45. Albashir, A.A.D. The potential impacts of obesity on COVID-19. Clin. Med. 2020, 20, e109-e113. [CrossRef] [PubMed]

46. Castañeda-Babarro, A.; Arbillaga-Etxarri, A.; Gutiérrez-Santamaría, B.; Coca, A. Physical Activity Change during COVID-19 Confinement. Int. J. Environ. Res. Public Health 2020, 17, 6878. [CrossRef]

47. Pellegrini, C.A.; Webster, J.; Hahn, K.R.; Leblond, T.L.; Unick, J.L. Relationship between stress and weight management behaviors during the COVID-19 pandemic among those enrolled in an internet program. Obes. Sci. Pract. 2021, 7, 129-134. [CrossRef] [PubMed]

48. Popkin, B.M.; Du, S.; Green, W.D.; Beck, M.A.; Algaith, T.; Herbst, C.H.; Alsukait, R.F.; Alluhidan, M.; Alazemi, N.; Shekar, M. Individuals with obesity and COVID-19: A global perspective on the epidemiology and biological relationships. Obes. Rev. 2020, 21, e13128. [CrossRef]

49. Petrakis, D.; Margină, D.; Tsarouhas, K.; Tekos, F.; Stan, M.; Nikitovic, D.; Kouretas, D.; Spandidos, D.A.; Tsatsakis, A. Obesity-A risk factor for increased COVID-19 prevalence, severity and lethality (Review). Mol. Med. Rep. 2020, 22, 9-19. [CrossRef] [PubMed]

50. Korakas, E.; Ikonomidis, I.; Kousathana, F.; Balampanis, K.; Kountouri, A.; Raptis, A.; Palaiodimou, L.; Kokkinos, A.; Lambadiari, V. Obesity and COVID-19: Immune and metabolic derangement as a possible link to adverse clinical outcomes. Am. J. Physiol. Endocrinol. Metab. 2020, 319, E105-E109. [CrossRef] 
51. Caci, G.; Albini, A.; Malerba, M.; Noonan, D.M.; Pochetti, P.; Polosa, R. COVID-19 and Obesity: Dangerous Liaisons. J. Clin. Med. 2020, 9, 2511. [CrossRef]

52. Ritter, A.; Kreis, N.N.; Louwen, F.; Yuan, J. Obesity and COVID-19: Molecular Mechanisms Linking Both Pandemics. Int. J. Mol. Sci. 2020, 21, 5793. [CrossRef] [PubMed]

53. Verma, S.; Hussain, M.E. Obesity and diabetes: An update. Diabetes Metab. Syndr. 2017, 11, 73-79. [CrossRef]

54. Malone, J.I.; Hansen, B.C. Does obesity cause type 2 diabetes mellitus (T2DM)? Or is it the opposite? Pediatr. Diabetes 2019, 20, 5-9. [CrossRef]

55. Zhou, Y.; Chi, J.; Lv, W.; Wang, Y. Obesity and diabetes as high-risk factors for severe coronavirus disease 2019 (COVID-19). Diabetes Metab. Res. Rev. 2021, 37, e3377. [CrossRef]

56. Landstra, C.P.; de Koning, E.J.P. COVID-19 and Diabetes: Understanding the Interrelationship and Risks for a Severe Course. Front. Endocrinol. 2021, 12, 649525. [CrossRef] [PubMed]

57. Rajpal, A.; Rahimi, L.; Ismail-Beigi, F. Factors leading to high morbidity and mortality of COVID-19 in patients with type 2 diabetes. J. Diabetes 2020, 12, 895-908. [CrossRef] [PubMed]

58. Neeland, I.J.; Poirier, P.; Després, J.P. Cardiovascular and Metabolic Heterogeneity of Obesity: Clinical Challenges and Implications for Management. Circulation 2018, 137, 1391-1406. [CrossRef]

59. Ferrara, D.; Montecucco, F.; Dallegri, F.; Carbone, F. Impact of different ectopic fat depots on cardiovascular and metabolic diseases. J. Cell Physiol. 2019, 234, 21630-21641. [CrossRef]

60. Del Turco, S.; Vianello, A.; Ragusa, R.; Caselli, C.; Basta, G. COVID-19 and cardiovascular consequences: Is the endothelial dysfunction the hardest challenge? Thromb. Res. 2020, 196, 143-151. [CrossRef]

61. Lima-Martínez, M.M.; Carrera Boada, C.; Madera-Silva, M.D.; Marín, W.; Contreras, M. COVID-19 and diabetes: A bidirectional relationship. Clin. Investig. Arterioscler. 2021, 33, 151-157. [CrossRef] [PubMed]

62. Ghanemi, A.; Yoshioka, M.; St-Amand, J. Post-Coronavirus Disease-2019 (COVID-19): Toward a Severe Multi-Level Health Crisis? Med. Sci. 2021, 9, 68. [CrossRef] [PubMed]

63. Soleimanpour, S.; Yaghoubi, A. COVID-19 vaccine: Where are we now and where should we go? Expert Rev. Vaccines 2021, 20, 23-44. [CrossRef] [PubMed]

64. Tremmel, M.; Gerdtham, U.G.; Nilsson, P.M.; Saha, S. Economic Burden of Obesity: A Systematic Literature Review. Int. J. Environ. Res. Public Health 2017, 14, 435. [CrossRef]

65. Cole, A.G.; Laxer, R.E.; Leatherdale, S. Social Consequences of Overweight and Obesity among Ontario High School Students. Can. J. Diabetes 2015, 39, S67. [CrossRef]

66. Bacchini, D.; Licenziati, M.R.; Garrasi, A.; Corciulo, N.; Driul, D.; Tanas, R.; Fiumani, P.M.; Di Pietro, E.; Pesce, S.; Crinò, A.; et al. Bullying and Victimization in Overweight and Obese Outpatient Children and Adolescents: An Italian Multicentric Study. PLoS ONE 2015, 10, e0142715. [CrossRef] [PubMed]

67. Jackson, V.M.; Breen, D.M.; Fortin, J.P.; Liou, A.; Kuzmiski, J.B.; Loomis, A.K.; Rives, M.L.; Shah, B.; Carpino, P.A. Latest approaches for the treatment of obesity. Expert Opin. Drug Discov. 2015, 10, 825-839. [CrossRef]

68. Rebello, C.J.; Greenway, F.L. Obesity medications in development. Expert Opin. Investig. Drugs 2020, 29, 63-71. [CrossRef]

69. Petridou, A.; Siopi, A.; Mougios, V. Exercise in the management of obesity. Metabolism 2019, 92, 163-169. [CrossRef] [PubMed]

70. Fonseca-Junior, S.J.; Sá, C.G.; Rodrigues, P.A.; Oliveira, A.J.; Fernandes-Filho, J. Physical exercise and morbid obesity: A systematic review. Arq. Bras. Cir. Dig. 2013, 26 (Suppl. 1), 67-73. [CrossRef]

71. Fock, K.M.; Khoo, J. Diet and exercise in management of obesity and overweight. J. Gastroenterol. Hepatol. 2013, 28 (Suppl. 4), 59-63. [CrossRef]

72. Ikeda, K.; Yamada, T. UCP1 Dependent and Independent Thermogenesis in Brown and Beige Adipocytes. Front. Endocrinol. 2020, 11, 498. [CrossRef]

73. Harvey-Berino, J. Calorie restriction is more effective for obesity treatment than dietary fat restriction. Ann. Behav. Med. 1999, 21, 35-39. [CrossRef]

74. Avena, N.M.; Rada, P.; Hoebel, B.G. Evidence for sugar addiction: Behavioral and neurochemical effects of intermittent, excessive sugar intake. Neurosci. Biobehav. Rev. 2008, 32, 20-39. [CrossRef] [PubMed]

75. Lennerz, B.; Lennerz, J.K. Food Addiction, High-Glycemic-Index Carbohydrates, and Obesity. Clin. Chem. 2018, 64, 64-71. [CrossRef]

76. Ghosh, S.; O'Connell, J.F.; Carlson, O.D.; González-Mariscal, I.; Kim, Y.; Moaddel, R.; Ghosh, P.; Egan, J.M. Linoleic acid in diets of mice increases total endocannabinoid levels in bowel and liver: Modification by dietary glucose. Obes. Sci. Pract. 2019, 5, 383-394. [CrossRef]

77. Lecheminant, J.D.; Gibson, C.A.; Sullivan, D.K.; Hall, S.; Washburn, R.; Vernon, M.C.; Curry, C.; Stewart, E.; Westman, E.C.; Donnelly, J.E. Comparison of a low carbohydrate and low fat diet for weight maintenance in overweight or obese adults enrolled in a clinical weight management program. Nutr. J. 2007, 6, 36. [CrossRef]

78. Brinkworth, G.D.; Wycherley, T.P.; Noakes, M.; Buckley, J.D.; Clifton, P.M. Long-term effects of a very-low-carbohydrate weight-loss diet and an isocaloric low-fat diet on bone health in obese adults. Nutrition 2016, 32, 1033-1036. [CrossRef] [PubMed]

79. LeCheminant, J.D.; Smith, B.K.; Westman, E.C.; Vernon, M.C.; Donnelly, J.E. Comparison of a reduced carbohydrate and reduced fat diet for LDL, HDL, and VLDL subclasses during 9-months of weight maintenance subsequent to weight loss. Lipids Health Dis. 2010, 9, 54. [CrossRef] 
80. Meckling, K.A.; O'Sullivan, C.; Saari, D. Comparison of a low-fat diet to a low-carbohydrate diet on weight loss, body composition, and risk factors for diabetes and cardiovascular disease in free-living, overweight men and women. J. Clin. Endocrinol. Metab. 2004, 89, 2717-2723. [CrossRef] [PubMed]

81. Schlundt, D.G.; Hill, J.O.; Pope-Cordle, J.; Arnold, D.; Virts, K.L.; Katahn, M. Randomized evaluation of a low fat ad libitum carbohydrate diet for weight reduction. Int. J. Obes. Relat. Metab. Disord. 1993, 17, 623-629.

82. Astrup, A.; Astrup, A.; Buemann, B.; Flint, A.; Raben, A. Low-fat diets and energy balance: How does the evidence stand in 2002? Proc. Nutr. Soc. 2002, 61, 299-309. [CrossRef] [PubMed]

83. Astrup, A. The role of dietary fat in the prevention and treatment of obesity. Efficacy and safety of low-fat diets. Int. J. Obes. Relat. Metab. Disord. 2001, 25 (Suppl. 1), S46-S50. [CrossRef] [PubMed]

84. Hunter, P.M.; Hegele, R.A. Functional foods and dietary supplements for the management of dyslipidaemia. Nat. Rev. Endocrinol. 2017, 13, 278-288. [CrossRef]

85. Asgary, S.; Rastqar, A.; Keshvari, M. Functional Food and Cardiovascular Disease Prevention and Treatment: A Review. J. Am. Coll. Nutr. 2018, 37, 429-455. [CrossRef] [PubMed]

86. Alkhatib, A.; Tsang, C.; Tiss, A.; Bahorun, T.; Arefanian, H.; Barake, R.; Khadir, A.; Tuomilehto, J. Functional Foods and Lifestyle Approaches for Diabetes Prevention and Management. Nutrients 2017, 9, 1310. [CrossRef]

87. Aronson, J.K. Defining Nutraceuticals: Neither nutritious nor pharmaceutical. Br. J. Clin. Pharm. 2017, 83, 8-19. [CrossRef]

88. Sachdeva, V.; Roy, A.; Bharadvaja, N. Current Prospects of Nutraceuticals: A Review. Curr. Pharm. Biotechnol. 2020, 21, 884-896. [CrossRef]

89. Tramontin, N.D.S.; Luciano, T.F.; Marques, S.O.; de Souza, C.T.; Muller, A.P. Ginger and avocado as nutraceuticals for obesity and its comorbidities. Phytother. Res. 2020, 34, 1282-1290. [CrossRef]

90. Manganaris, G.A.; Goulas, V.; Vicente, A.R.; Terry, L.A. Berry antioxidants: Small fruits providing large benefits. J. Sci. Food Agric. 2014, 94, 825-833. [CrossRef]

91. Skrovankova, S.; Sumczynski, D.; Mlcek, J.; Jurikova, T.; Sochor, J. Bioactive Compounds and Antioxidant Activity in Different Types of Berries. Int. J. Mol. Sci. 2015, 16, 24673-24706. [CrossRef] [PubMed]

92. Zhu, F.; Du, B.; Xu, B. Anti-inflammatory effects of phytochemicals from fruits, vegetables, and food legumes: A review. Crit. Rev. Food Sci. Nutr. 2018, 58, 1260-1270. [CrossRef] [PubMed]

93. Maleki, S.J.; Crespo, J.F.; Cabanillas, B. Anti-inflammatory effects of flavonoids. Food Chem 2019, 299, 125124. [CrossRef] [PubMed]

94. Şanlier, N.; Gökcen, B.B.; Sezgin, A.C. Health benefits of fermented foods. Crit. Rev. Food Sci. Nutr. 2019, 59, 506-527. [CrossRef] [PubMed]

95. Baby, B.; Antony, P.; Vijayan, R. Antioxidant and anticancer properties of berries. Crit. Rev. Food Sci. Nutr. 2018, 58, 2491-2507. [CrossRef]

96. Boivin, D.; Blanchette, M.; Barrette, S.; Moghrabi, A.; Béliveau, R. Inhibition of cancer cell proliferation and suppression of TNF-induced activation of NFkappaB by edible berry juice. Anticancer Res. 2007, 27, 937-948.

97. Sekizawa, H.; Ikuta, K.; Mizuta, K.; Takechi, S.; Suzutani, T. Relationship between polyphenol content and anti-influenza viral effects of berries. J. Sci. Food Agric. 2013, 93, 2239-2241. [CrossRef] [PubMed]

98. Slavin, J. Fiber and prebiotics: Mechanisms and health benefits. Nutrients 2013, 5, 1417-1435. [CrossRef]

99. Choi, B.S.; Varin, T.V.; St-Pierre, P.; Pilon, G.; Tremblay, A.; Marette, A. A polyphenol-rich cranberry extract protects against endogenous exposure to persistent organic pollutants during weight loss in mice. Food Chem. Toxicol. 2020, 146, 111832. [CrossRef]

100. Pannu, P.K.; Calton, E.K.; Soares, M.J. Calcium and Vitamin D in Obesity and Related Chronic Disease. Adv. Food Nutr. Res. 2016, 77, 57-100. [CrossRef]

101. Kuroda, M.; Sakaue, H. Role of vitamin D and calcium in obesity and type 2 diabetes. Clin. Calcium. 2016, 26, 349-354. [PubMed]

102. Sathyamoorthy, N.; Wang, T.T.; Phang, J.M. Stimulation of pS2 expression by diet-derived compounds. Cancer Res. 1994, 54, 957-961. [PubMed]

103. Van Horn, L.; Huffman, M.D. Eat to Treat Heart Failure. Circ. Heart Fail. 2018, 11, e005367. [CrossRef]

104. Angelidi, A.M.; Kokkinos, A.; Katechaki, E.; Ros, E.; Mantzoros, C.S. Mediterranean diet as a nutritional approach for COVID-19. Metabolism 2021, 114, 154407. [CrossRef]

105. Yoshioka, M.; St-Pierre, S.; Drapeau, V.; Dionne, I.; Doucet, E.; Suzuki, M.; Tremblay, A. Effects of red pepper on appetite and energy intake. Br. J. Nutr. 1999, 82, 115-123. [CrossRef]

106. Yoshioka, M.; Imanaga, M.; Ueyama, H.; Yamane, M.; Kubo, Y.; Boivin, A.; St-Amand, J.; Tanaka, H.; Kiyonaga, A. Maximum tolerable dose of red pepper decreases fat intake independently of spicy sensation in the mouth. Br. J. Nutr. 2004, 91, 991-995. [CrossRef] [PubMed]

107. Westerterp-Plantenga, M.S.; Smeets, A.; Lejeune, M.P. Sensory and gastrointestinal satiety effects of capsaicin on food intake. Int. J. Obes. 2005, 29, 682-688. [CrossRef]

108. Cani, P.D.; Joly, E.; Horsmans, Y.; Delzenne, N.M. Oligofructose promotes satiety in healthy human: A pilot study. Eur. J. Clin. Nutr. 2006, 60, 567-572. [CrossRef]

109. Howarth, N.C.; Saltzman, E.; Roberts, S.B. Dietary fiber and weight regulation. Nutr. Rev. 2001, 59, 129-139. [CrossRef]

110. Mathern, J.R.; Raatz, S.K.; Thomas, W.; Slavin, J.L. Effect of fenugreek fiber on satiety, blood glucose and insulin response and energy intake in obese subjects. Phytother. Res. 2009, 23, 1543-1548. [CrossRef] 
111. Choi, B.S.; Daniel, N.; Houde, V.P.; Ouellette, A.; Marcotte, B.; Varin, T.V.; Vors, C.; Feutry, P.; Ilkayeva, O.; Ståhlman, M.; et al. Feeding diversified protein sources exacerbates hepatic insulin resistance via increased gut microbial branched-chain fatty acids and mTORC1 signaling in obese mice. Nat. Commun. 2021, 12, 3377. [CrossRef]

112. Chevrier, G.; Mitchell, P.L.; Rioux, L.E.; Hasan, F.; Jin, T.; Roblet, C.R.; Doyen, A.; Pilon, G.; St-Pierre, P.; Lavigne, C.; et al. LowMolecular-Weight Peptides from Salmon Protein Prevent Obesity-Linked Glucose Intolerance, Inflammation, and Dyslipidemia in LDLR-/-/ApoB100/100 Mice. J. Nutr. 2015, 145, 1415-1422. [CrossRef] [PubMed]

113. Samane, S.; Christon, R.; Dombrowski, L.; Turcotte, S.; Charrouf, Z.; Lavigne, C.; Levy, E.; Bachelard, H.; Amarouch, H.; Marette, A.; et al. Fish oil and argan oil intake differently modulate insulin resistance and glucose intolerance in a rat model of dietary-induced obesity. Metabolism 2009, 58, 909-919. [CrossRef] [PubMed]

114. Steerenberg, P.A.; Beekhof, P.K.; Feskens, E.J.; Lips, C.J.; Höppener, J.W.; Beems, R.B. Long-term effect of fish oil diet on basal and stimulated plasma glucose and insulin levels in ob/ob mice. Diabetes Nutr. Metab. 2002, 15, 205-214.

115. Gao, X.; Xu, J.; Jiang, C.; Zhang, Y.; Xue, Y.; Li, Z.; Wang, J.; Xue, C.; Wang, Y. Fish oil ameliorates trimethylamine N-oxideexacerbated glucose intolerance in high-fat diet-fed mice. Food Funct. 2015, 6, 1117-1125. [CrossRef]

116. Fedor, D.; Kelley, D.S. Prevention of insulin resistance by n-3 polyunsaturated fatty acids. Curr. Opin. Clin. Nutr. Metab. Care 2009, 12, 138-146. [CrossRef] [PubMed]

117. Baynes, H.W.; Mideksa, S.; Ambachew, S. The role of polyunsaturated fatty acids (n-3 PUFAs) on the pancreatic $\beta$-cells and insulin action. Adipocyte 2018, 7, 81-87. [CrossRef]

118. Richards, P.; Pais, R.; Habib, A.M.; Brighton, C.A.; Yeo, G.S.; Reimann, F.; Gribble, F.M. High fat diet impairs the function of glucagon-like peptide-1 producing L-cells. Peptides 2016, 77, 21-27. [CrossRef]

119. Grabauskas, G.; Wu, X.; Zhou, S.; Li, J.; Gao, J.; Owyang, C. High-fat diet-induced vagal afferent dysfunction via upregulation of 2-pore domain potassium TRESK channel. JCI Insight 2019, 4, e130402. [CrossRef]

120. Grigorova, N.; Ivanova, Z.; Bjorndal, B.; Vachkova, E.; Penchev, G.; Berge, R.; Ribarski, S.; Georgieva, T.M.; Yonkova, P.; Georgiev, I.P. Effect of fish oil supplementation and restricted feeding on body fat distribution and blood lipid profile in a rabbit model of castration-induced obesity. Res. Vet. Sci. 2019, 124, 99-105. [CrossRef]

121. Schubert, M.M.; Irwin, C.; Seay, R.F.; Clarke, H.E.; Allegro, D.; Desbrow, B. Caffeine, coffee, and appetite control: A review. Int. J. Food Sci. Nutr. 2017, 68, 901-912. [CrossRef]

122. Gavrieli, A.; Karfopoulou, E.; Kardatou, E.; Spyreli, E.; Fragopoulou, E.; Mantzoros, C.S.; Yannakoulia, M. Effect of different amounts of coffee on dietary intake and appetite of normal-weight and overweight/obese individuals. Obesity 2013, 21, 1127-1132. [CrossRef]

123. Ghanemi, A.; Melouane, A.; Yoshioka, M.; St-Amand, J. Exercise and High-Fat Diet in Obesity: Functional Genomics Perspectives of Two Energy Homeostasis Pillars. Genes 2020, 11, 875. [CrossRef] [PubMed]

124. Choi, B.S.; Daoust, L.; Pilon, G.; Marette, A.; Tremblay, A. Potential therapeutic applications of the gut microbiome in obesity: From brain function to body detoxification. Int. J. Obes. 2020, 44, 1818-1831. [CrossRef] [PubMed]

125. Bibbò, S.; Ianiro, G.; Giorgio, V.; Scaldaferri, F.; Masucci, L.; Gasbarrini, A.; Cammarota, G. The role of diet on gut microbiota composition. Eur. Rev. Med. Pharmacol. Sci. 2016, 20, 4742-4749.

126. Trefflich, I.; Jabakhanji, A.; Menzel, J.; Blaut, M.; Michalsen, A.; Lampen, A.; Abraham, K.; Weikert, C. Is a vegan or a vegetarian diet associated with the microbiota composition in the gut? Results of a new cross-sectional study and systematic review. Crit. Rev. Food Sci. Nutr. 2020, 60, 2990-3004. [CrossRef]

127. Barengolts, E. Gut microbiota, prebiotics, probiotics, and synbiotics in management of obesity and prediabetes: Review of randomized controlled trials. Endocr. Pract. 2016, 22, 1224-1234. [CrossRef]

128. da Silva, T.F.; Casarotti, S.N.; de Oliveira, G.L.V.; Penna, A.L.B. The impact of probiotics, prebiotics, and synbiotics on the biochemical, clinical, and immunological markers, as well as on the gut microbiota of obese hosts. Crit. Rev. Food Sci. Nutr. 2021, 61, 337-355. [CrossRef]

129. Aoun, A.; Darwish, F.; Hamod, N. The Influence of the Gut Microbiome on Obesity in Adults and the Role of Probiotics, Prebiotics, and Synbiotics for Weight Loss. Prev. Nutr. Food Sci. 2020, 25, 113-123. [CrossRef] [PubMed]

130. Gual-Grau, A.; Guirro, M.; Mayneris-Perxachs, J.; Arola, L.; Boqué, N. Impact of different hypercaloric diets on obesity features in rats: A metagenomics and metabolomics integrative approach. J. Nutr. Biochem. 2019, 71, 122-131. [CrossRef]

131. Jaiswal, S.; Libby, P. Clonal haematopoiesis: Connecting ageing and inflammation in cardiovascular disease. Nat. Rev. Cardiol. 2020, 17, 137-144. [CrossRef] [PubMed]

132. Bektas, A.; Schurman, S.H.; Sen, R.; Ferrucci, L. Aging, inflammation and the environment. Exp. Gerontol. 2018, 105, 10-18. [CrossRef]

133. Popa-Wagner, A.; Petcu, E.B.; Capitanescu, B.; Hermann, D.M.; Radu, E.; Gresita, A. Ageing as a risk factor for cerebral ischemia: Underlying mechanisms and therapy in animal models and in the clinic. Mech. Ageing Dev. 2020, 190, 111312. [CrossRef]

134. Aspray, T.J.; Hill, T.R. Osteoporosis and the Ageing Skeleton. Subcell. Biochem. 2019, 91, 453-476. [CrossRef] [PubMed]

135. Liguori, I.; Russo, G.; Curcio, F.; Bulli, G.; Aran, L.; Della-Morte, D.; Gargiulo, G.; Testa, G.; Cacciatore, F.; Bonaduce, D.; et al. Oxidative stress, aging, and diseases. Clin. Interv. Aging 2018, 13, 757-772. [CrossRef]

136. Hou, Y.; Dan, X.; Babbar, M.; Wei, Y.; Hasselbalch, S.G.; Croteau, D.L.; Bohr, V.A. Ageing as a risk factor for neurodegenerative disease. Nat. Rev. Neurol. 2019, 15, 565-581. [CrossRef] 
137. Kozakova, M.; Palombo, C. Vascular Ageing and Aerobic Exercise. Int. J. Environ. Res. Public Health 2021, 18, 666. [CrossRef] [PubMed]

138. Lee, P.G.; Jackson, E.A.; Richardson, C.R. Exercise Prescriptions in Older Adults. Am. Fam. Physician 2017, 95, 425-432.

139. Galloza, J.; Castillo, B.; Micheo, W. Benefits of Exercise in the Older Population. Phys. Med. Rehabil. Clin. N. Am. 2017, 28, 659-669. [CrossRef] [PubMed]

140. Ohayon, M.; Wickwire, E.M.; Hirshkowitz, M.; Albert, S.M.; Avidan, A.; Daly, F.J.; Dauvilliers, Y.; Ferri, R.; Fung, C.; Gozal, D.; et al. National Sleep Foundation's sleep quality recommendations: First report. Sleep Health 2017, 3, 6-19. [CrossRef]

141. Flicker, L.; Lautenschlager, N.T.; Almeida, O.P. Healthy mental ageing. J. Br. Menopause Soc. 2006, 12, 92-96. [CrossRef]

142. Luo, J.; Mills, K.; le Cessie, S.; Noordam, R.; van Heemst, D. Ageing, age-related diseases and oxidative stress: What to do next? Ageing. Res. Rev. 2020, 57, 100982. [CrossRef] [PubMed]

143. Davies, K.J.A. Free radicals and redox regulation in ageing. Free Radic. Biol. Med. 2019, 134, 688-689. [CrossRef] [PubMed]

144. Viña, J.; Borrás, C.; Miquel, J. Theories of ageing. IUBMB Life 2007, 59, 249-254. [CrossRef] [PubMed]

145. Pajares, M.; Cuadrado, A.; Engedal, N.; Jirsova, Z.; Cahova, M. The Role of Free Radicals in Autophagy Regulation: Implications for Ageing. Oxidative Med. Cell. Longev. 2018, 2018, 2450748. [CrossRef]

146. Dhanjal, D.S.; Bhardwaj, S.; Sharma, R.; Bhardwaj, K.; Kumar, D.; Chopra, C.; Nepovimova, E.; Singh, R.; Kuca, K. Plant Fortification of the Diet for Anti-Ageing Effects: A Review. Nutrients 2020, 12, 3008. [CrossRef]

147. Bramorska, A.; Zarzycka, W.; Podolecka, W.; Kuc, K.; Brzezicka, A. Age-Related Cognitive Decline May Be Moderated by Frequency of Specific Food Products Consumption. Nutrients 2021, 13, 2504. [CrossRef]

148. De la Fuente, M. Effects of antioxidants on immune system ageing. Eur. J. Clin. Nutr. 2002, 56 (Suppl. 3), S5-S8. [CrossRef]

149. Yin, Y.; Shan, H.Q.; Huang, W.; Wu, Y.M.; Lu, H.; Jin, Y. Bioinformatic analysis of miRNA expression patterns in TFF2 knock-out mice. Genet. Mol. Res. 2014, 13, 8502-8510. [CrossRef]

150. Aihara, E.; Engevik, K.A.; Montrose, M.H. Trefoil Factor Peptides and Gastrointestinal Function. Annu. Rev. Physiol. 2017, 79, 357-380. [CrossRef]

151. Thim, L.; May, F.E. Structure of mammalian trefoil factors and functional insights. Cell Mol. Life Sci. 2005, 62, $2956-2973$. [CrossRef] [PubMed]

152. Katoh, M. Trefoil factors and human gastric cancer (review). Int. J. Mol. Med. 2003, 12, 3-9. [CrossRef]

153. Dignass, A.; Lynch-Devaney, K.; Kindon, H.; Thim, L.; Podolsky, D.K. Trefoil peptides promote epithelial migration through a transforming growth factor beta-independent pathway. J. Clin. Investig. 1994, 94, 376-383. [CrossRef] [PubMed]

154. Taupin, D.; Podolsky, D.K. Trefoil factors: Initiators of mucosal healing. Nat. Rev. Mol. Cell Biol. 2003, 4, 721-732. [CrossRef]

155. Shah, A.A.; Leidinger, P.; Keller, A.; Wendschlag, A.; Meese, E.; Blin, N. Altered miRNA expression patterns in Tff2 knock-out mice correlate with cellular pathways of neoplastic development and caloric metabolism. Int. J. Mol. Med. 2012, 29, 637-643. [CrossRef] [PubMed]

156. Braga Emidio, N.; Brierley, S.M.; Schroeder, C.I.; Muttenthaler, M. Structure, Function, and Therapeutic Potential of the Trefoil Factor Family in the Gastrointestinal Tract. ACS Pharm. Transl. Sci. 2020, 3, 583-597. [CrossRef]

157. Xue, Y.; Shen, L.; Cui, Y.; Zhang, H.; Chen, Q.; Cui, A.; Fang, F.; Chang, Y. Tff3, as a novel peptide, regulates hepatic glucose metabolism. PLoS ONE 2013, 8, e75240. [CrossRef]

158. Arnold, P.; Rickert, U.; Helmers, A.K.; Spreu, J.; Schneppenheim, J.; Lucius, R. Trefoil factor 3 shows anti-inflammatory effects on activated microglia. Cell Tissue Res. 2016, 365, 3-11. [CrossRef]

159. Braga Emidio, N.; Meli, R.; Tran, H.N.T.; Baik, H.; Morisset-Lopez, S.; Elliott, A.G.; Blaskovich, M.A.T.; Spiller, S.; Beck-Sickinger, A.G.; Schroeder, C.I.; et al. Chemical Synthesis of TFF3 Reveals Novel Mechanistic Insights and a Gut-Stable Metabolite. J. Med. Chem. 2021, 64, 9484-9495. [CrossRef]

160. Belle, N.M.; Ji, Y.; Herbine, K.; Wei, Y.; Park, J.; Zullo, K.; Hung, L.Y.; Srivatsa, S.; Young, T.; Oniskey, T.; et al. TFF3 interacts with LINGO2 to regulate EGFR activation for protection against colitis and gastrointestinal helminths. Nat. Commun. 2019, 10, 4408. [CrossRef]

161. Ge, H.; Gardner, J.; Wu, X.; Rulifson, I.; Wang, J.; Xiong, Y.; Ye, J.; Belouski, E.; Cao, P.; Tang, J.; et al. Trefoil Factor 3 (TFF3) Is Regulated by Food Intake, Improves Glucose Tolerance and Induces Mucinous Metaplasia. PLoS ONE 2015, 10, e0126924. [CrossRef] [PubMed]

162. Bujak, M.; Bujak, I.T.; Sobočanec, S.; Mihalj, M.; Novak, S.; Ćosić, A.; Levak, M.T.; Kopačin, V.; Mihaljević, B.; Balog, T.; et al. Trefoil Factor 3 Deficiency Affects Liver Lipid Metabolism. Cell. Physiol. Biochem. Int. J. Exp. Cell. Physiol. Biochem. Pharmacol. 2018, 47, 827-841. [CrossRef] [PubMed]

163. Wu, X.; Zheng, H.; Yang, R.; Luan, X.; Zhang, L.; Jin, Q.; Jin, Y.; Xue, J. Mouse trefoil factor 3 ameliorated high-fat-diet-induced hepatic steatosis via increasing peroxisome proliferator-activated receptor- $\alpha$-mediated fatty acid oxidation. Am. J. Physiol. Endocrinol. Metab. 2019, 317, E436-E445. [CrossRef] [PubMed]

164. Judd, L.M.; Chalinor, H.V.; Walduck, A.; Pavlic, D.I.; Däbritz, J.; Dubeykovskaya, Z.; Wang, T.C.; Menheniott, T.R.; Giraud, A.S. TFF2 deficiency exacerbates weight loss and alters immune cell and cytokine profiles in DSS colitis, and this cannot be rescued by wild-type bone marrow. Am. J. Physiol. Gastrointest. Liver Physiol. 2015, 308, G12-G24. [CrossRef]

165. Kurt-Jones, E.A.; Cao, L.; Sandor, F.; Rogers, A.B.; Whary, M.T.; Nambiar, P.R.; Cerny, A.; Bowen, G.; Yan, J.; Takaishi, S.; et al Trefoil family factor 2 is expressed in murine gastric and immune cells and controls both gastrointestinal inflammation and systemic immune responses. Infect. Immun. 2007, 75, 471-480. [CrossRef] 
166. De Giorgio, M.R.; Yoshioka, M.; Riedl, I.; Moreault, O.; Cherizol, R.G.; Shah, A.A.; Blin, N.; Richard, D.; St-Amand, J. Trefoil factor family member 2 (Tff2) KO mice are protected from high-fat diet-induced obesity. Obesity 2013, 21, 1389-1395. [CrossRef]

167. Lebherz-Eichinger, D.; Tudor, B.; Ankersmit, H.J.; Reiter, T.; Haas, M.; Einwallner, E.; Roth-Walter, F.; Krenn, C.G.; Roth, G.A. Increased trefoil factor 2 levels in patients with chronic kidney disease. PLoS ONE 2017, 12, e0174551. [CrossRef] [PubMed]

168. Ghanemi, A.; Yoshioka, M.; St-Amand, J. Trefoil Factor Family Member 2 (TFF2) as an Inflammatory-Induced and AntiInflammatory Tissue Repair Factor. Animals 2020, 10, 1646. [CrossRef]

169. Ghanemi, A.; Yoshioka, M.; St-Amand, J. High-Fat Diet-Induced Trefoil Factor Family Member 2 (TFF2) to Counteract the Immune-Mediated Damage in Mice. Animals 2021, 11, 258. [CrossRef]

170. Baus-Loncar, M.; Kayademir, T.; Takaishi, S.; Wang, T. Trefoil factor family 2 deficiency and immune response. Cell. Mol. Life Sci. 2005, 62, 2947-2955. [CrossRef]

171. Yoshioka, M.; Bolduc, C.; Raymond, V.; St-Amand, J. High-fat meal-induced changes in the duodenum mucosa transcriptome. Obesity 2008, 16, 2302-2307. [CrossRef]

172. Mucunguzi, O.; Melouane, A.; Ghanemi, A.; Yoshioka, M.; Boivin, A.; Calvo, E.L.; St-Amand, J. Identification of the principal transcriptional regulators for low-fat and high-fat meal responsive genes in small intestine. Nutr. Metab. 2017, 14, 66. [CrossRef]

173. Ghanemi, A.; Yoshioka, M.; St-Amand, J. Trefoil Factor Family Member 2 Expression as an Indicator of the Severity of the High-Fat Diet-Induced Obesity. Genes 2021, 12, 1505. [CrossRef]

174. Ghanemi, A.; Melouane, A.; Mucunguzi, O.; Yoshioka, M.; St-Amand, J. Energy and metabolic pathways in trefoil factor family member 2 (Tff2) KO mice beyond the protection from high-fat diet-induced obesity. Life Sci. 2018, 215, 190-197. [CrossRef]

175. Ghanemi, A.; Yoshioka, M.; St-Amand, J. Trefoil Factor Family Member 2: From a High-Fat-Induced Gene to a Potential Obesity Therapy Target. Metabolites 2021, 11, 536. [CrossRef] [PubMed]

176. Wu, B.; Chien, E.Y.; Mol, C.D.; Fenalti, G.; Liu, W.; Katritch, V.; Abagyan, R.; Brooun, A.; Wells, P.; Bi, F.C.; et al. Structures of the CXCR4 chemokine GPCR with small-molecule and cyclic peptide antagonists. Science 2010, 330, 1066-1071. [CrossRef]

177. Ghanemi, A. Targeting G protein coupled receptor-related pathways as emerging molecular therapies. Saudi Pharm. J. 2015, 23, 115-129. [CrossRef] [PubMed]

178. Dubeykovskaya, Z.; Dubeykovskiy, A.; Solal-Cohen, J.; Wang, T.C. Secreted trefoil factor 2 activates the CXCR4 receptor in epithelial and lymphocytic cancer cell lines. J. Biol. Chem. 2009, 284, 3650-3662. [CrossRef] [PubMed]

179. Hirata, K.; Kodama, S.; Nakano, Y.; Minaki-Nakagawa, Y.; Aoyama, Y.; Sakikubo, M.; Goto, T.; Yoshida, M.; Masui, T.; Yamamoto, T.; et al. Exocrine tissue-driven TFF2 prevents apoptotic cell death of endocrine lineage during pancreas organogenesis. Sci Rep. 2019, 9, 1636. [CrossRef] [PubMed]

180. Orime, K.; Shirakawa, J.; Togashi, Y.; Tajima, K.; Inoue, H.; Ito, Y.; Sato, K.; Nakamura, A.; Aoki, K.; Goshima, Y.; et al. Trefoil factor 2 promotes cell proliferation in pancreatic $\beta$-cells through CXCR-4-mediated ERK1/2 phosphorylation. Endocrinology 2013, 154, 54-64. [CrossRef] [PubMed]

181. Guo, Z.; Chen, W.; Dai, G.; Huang, Y. Cordycepin suppresses the migration and invasion of human liver cancer cells by downregulating the expression of CXCR4. Int. J. Mol. Med. 2020, 45, 141-150. [CrossRef]

182. Yao, L.; Heuser-Baker, J.; Herlea-Pana, O.; Zhang, N.; Szweda, L.I.; Griffin, T.M.; Barlic-Dicen, J. Deficiency in adipocyte chemokine receptor CXCR4 exacerbates obesity and compromises thermoregulatory responses of brown adipose tissue in a mouse model of diet-induced obesity. FASEB J. 2014, 28, 4534-4550. [CrossRef]

183. Mouhieddine, T.H.; Ahmad, Y.; Barlogie, B.; Jagannath, S.; Teruya-Feldstein, J.; Richter, J. Increased Muscle CXCR4 Expression in the Setting of Rare Muscle-invasive Multiple Myeloma. Clin. Lymphoma Myeloma Leuk. 2020, 20, e341-e344. [CrossRef]

184. Banisadr, G.; Fontanges, P.; Haour, F.; Kitabgi, P.; Rostène, W.; Mélik Parsadaniantz, S. Neuroanatomical distribution of CXCR4 in adult rat brain and its localization in cholinergic and dopaminergic neurons. Eur. J. Neurosci. 2002, 16, 1661-1671. [CrossRef]

185. Jiang, Q.; Sun, Y.; Liu, X. CXCR4 as a prognostic biomarker in gastrointestinal cancer: A meta-analysis. Biomarkers 2019, 24, 510-516. [CrossRef]

186. Urosevic, J.; Blasco, M.T.; Llorente, A.; Bellmunt, A.; Berenguer-Llergo, A.; Guiu, M.; Cañellas, A.; Fernandez, E.; Burkov, I.; Clapés, M.; et al. ERK1/2 Signaling Induces Upregulation of ANGPT2 and CXCR4 to Mediate Liver Metastasis in Colon Cancer. Cancer Res. 2020, 80, 4668-4680. [CrossRef]

187. Shibata, M.; Banno, R.; Sugiyama, M.; Tominaga, T.; Onoue, T.; Tsunekawa, T.; Azuma, Y.; Hagiwara, D.; Lu, W.; Ito, Y.; et al. AgRP Neuron-Specific Deletion of Glucocorticoid Receptor Leads to Increased Energy Expenditure and Decreased Body Weight in Female Mice on a High-Fat Diet. Endocrinology 2016, 157, 1457-1466. [CrossRef] [PubMed]

188. Lu, X.Y. Role of central melanocortin signaling in eating disorders. Psychopharmacol. Bull. 2001, 35, 45-65. [PubMed]

189. Benoit, S.; Schwartz, M.; Baskin, D.; Woods, S.C.; Seeley, R.J. CNS melanocortin system involvement in the regulation of food intake. Horm. Behav. 2000, 37, 299-305. [CrossRef] [PubMed]

190. Biebermann, H.; Kühnen, P.; Kleinau, G.; Krude, H. The neuroendocrine circuitry controlled by POMC, MSH, and AGRP. Handb. Exp. Pharm. 2012, 209, 47-75. [CrossRef]

191. Seeley, R.J.; Drazen, D.L.; Clegg, D.J. The critical role of the melanocortin system in the control of energy balance. Annu. Rev. Nutr. 2004, 24, 133-149. [CrossRef] [PubMed]

192. Farrell, J.J.; Taupin, D.; Koh, T.J.; Chen, D.; Zhao, C.M.; Podolsky, D.K.; Wang, T.C. TFF2/SP-deficient mice show decreased gastric proliferation, increased acid secretion, and increased susceptibility to NSAID injury. J. Clin. Investig. 2002, 109, 193-204. [CrossRef] [PubMed] 
193. Scholven, J.; Taras, D.; Sharbati, S.; Schön, J.; Gabler, C.; Huber, O.; Meyer zum Büschenfelde, D.; Blin, N.; Einspanier, R. Intestinal expression of TFF and related genes during postnatal development in a piglet probiotic trial. Cell. Physiol. Biochem. Int. J. Exp. Cell. Physiol. Biochem. Pharmacol. 2009, 23, 143-156. [CrossRef]

194. Dossinger, V.; Kayademir, T.; Blin, N.; Gött, P. Down-regulation of TFF expression in gastrointestinal cell lines by cytokines and nuclear factors. Cell. Physiol. Biochem. 2002, 12, 197-206. [CrossRef]

195. Capuano, E.; Janssen, A.E.M. Food Matrix and Macronutrient Digestion. Annu. Rev. Food Sci. Technol. 2021, 12, 193-212. [CrossRef] [PubMed]

196. Nieva-Echevarría, B.; Goicoechea, E.; Guillén, M.D. Food lipid oxidation under gastrointestinal digestion conditions: A review. Crit. Rev. Food Sci. Nutr. 2020, 60, 461-478. [CrossRef]

197. Raka, F.; Farr, S.; Kelly, J.; Stoianov, A.; Adeli, K. Metabolic control via nutrient-sensing mechanisms: Role of taste receptors and the gut-brain neuroendocrine axis. Am. J. Physiol. Endocrinol. Metab. 2019, 317, E559-E572. [CrossRef]

198. Vettor, R.; Di Vincenzo, A.; Maffei, P.; Rossato, M. Regulation of energy intake and mechanisms of metabolic adaptation or maladaptation after caloric restriction. Rev. Endocr. Metab. Disord. 2020, 21, 399-409. [CrossRef]

199. Jequier, E. Leptin signaling, adiposity, and energy balance. Ann. N. Y. Acad. Sci. 2002, 967, 379-388. [CrossRef]

200. Frühbeck, G.; Catalán, V.; Rodríguez, A.; Gómez-Ambrosi, J. Adiponectin-leptin ratio: A promising index to estimate adipose tissue dysfunction. Relation with obesity-associated cardiometabolic risk. Adipocyte 2018, 7, 57-62. [CrossRef] [PubMed]

201. Rebello, C.J.; Kirwan, J.P.; Greenway, F.L. Obesity, the most common comorbidity in SARS-CoV-2: Is leptin the link? Int. J. Obes. 2020, 44, 1810-1817. [CrossRef]

202. Ishioka, K.; Hatai, H.; Komabayashi, K.; Soliman, M.M.; Shibata, H.; Honjoh, T.; Kimura, K.; Saito, M. Diurnal variations of serum leptin in dogs: Effects of fasting and re-feeding. Vet. J. 2005, 169, 85-90. [CrossRef]

203. Kiani, A. Temporal Changes in Plasma Concentration of Leptin, IGF-1, Insulin and Metabolites Under Extended Fasting and Re-Feeding Conditions in Growing Lambs. Int. J. Endocrinol. Metab. 2013, 11, 34-40. [CrossRef]

204. Lee, Y.C.; Ko, Y.H.; Hsu, Y.P.; Ho, L.T. Plasma leptin response to oral glucose tolerance and fasting/re-feeding tests in rats with fructose-induced metabolic derangements. Life Sci. 2006, 78, 1155-1162. [CrossRef]

205. Ronis, M.J.J.; Pedersen, K.B.; Watt, J. Adverse Effects of Nutraceuticals and Dietary Supplements. Annu. Rev. Pharm. Toxicol. 2018, 58, 583-601. [CrossRef]

206. Ghanemi, A. Is mapping borders between pharmacology and toxicology a necessity? Saudi Pharm. J. 2014, 22, 489-490. [CrossRef]

207. Ghanemi, A. How to define a pharmacological or a toxic food? Alex. J. Med. 2015, 51, 359-360. [CrossRef]

208. Ghanemi, A. Cell cultures in drug development: Applications, challenges and limitations. Saudi Pharm. J. 2015, $23,453-454$. [CrossRef] [PubMed]

209. Thérien, A.; Cieślak, A.; Verreault, M.; Perreault, M.; Trottier, J.; Gobeil, S.; Vohl, M.-C.; Barbier, O. Omega-3 Polyunsaturated Fatty Acid: A Pharmaco-Nutraceutical Approach to Improve the Responsiveness to Ursodeoxycholic Acid. Nutrients 2021, $13,2617$. [CrossRef]

210. Kalra, E.K. Nutraceutical-definition and introduction. AAPS Pharm. Sci. 2003, 5, E25. [CrossRef] [PubMed] 